\title{
The development of a ground support design strategy for deep mines subjected to dynamic-loading conditions
}

\author{
P Morissette Agnico Eagle Mines Limited, Canada \\ J Hadjigeorgiou University of Toronto, Canada
}

\begin{abstract}
In underground mines, a ground support system is required to maintain the integrity of an excavation over its service life. The design of support systems typically accounts for the anticipated static loads and is, to some extent, supported by quantitative engineering guidelines. In deep and high stress mines, dynamic loads associated with mining-induced seismicity represent an important component of the demand imposed on the support. Quantifying dynamic loads that apply on, and between, reinforcement and surface support elements is an important challenge. In this respect, the design of ground support systems for dynamic-loading conditions has relied importantly on qualitative assessments of support performance.

This paper presents a ground support design strategy, supported by high-quality field data, for deep and high stress mines subjected to dynamic-loading conditions. The strategy has been developed and validated using rockburst data from three seismically active mines located in the Sudbury region, Canada, and cumulating 32 years of mining.
\end{abstract}

Keywords: ground support design, seismicity, rockbursts

\section{Introduction}

In underground mines, ground support is required to maintain the integrity of an excavation over its service life. The design of ground support systems typically accounts for the anticipated static loads and is, to some extent, supported by quantitative engineering guidelines. In deep and high stress mines, dynamic loads associated with mining-induced seismicity represent an important component of the demand imposed on the support. Quantifying dynamic loads that apply on, and between, reinforcement and surface support elements is an important challenge. The design of ground support systems for dynamic-loading conditions has relied on local experience and perceived performance.

In deep and high stress mines, a ground support system is expected to:

- Prevent excessive levels of rock mass dilation in order to maintain confinement around the reinforcement elements.

- Absorb kinetic energy released through the process of brittle rock mass failure and ejection.

- Maintain the integrity of its connections, which are often perceived as the system's weakest link.

This paper presents a ground support design strategy, supported by high-quality field data, for deep and high stress mines subjected to dynamic-loading conditions. The strategy has been developed and validated using rockburst data from three seismically active mines located in the Sudbury area in Canada and cumulating 32 years of mining. The developed ground support strategy addresses:

- The seismic risk assessment based on anticipated event magnitudes.

- The zoning of mine locations in which the installation of enhanced support is recommended.

- The timing of enhanced support installation.

- The composition of the enhanced ground support system. 
In this paper, 'enhanced support' refers to ground support systems that were reinforced in order to face and manage dynamic-loading conditions. Although the specific recommendations from this paper can be mine- or region-specific, the methodology applied for developing this ground support design strategy can be transferred to other mine sites.

\section{Passive monitoring of ground support performance}

Passive monitoring of real events is a valuable tool to assess the performance of ground support systems. A comprehensive rockburst data collection campaign was undertaken in three deep and high stress mines located in the Sudbury region, in Ontario, Canada (Morissette et al. 2014a). These mines were selected based on their history of rockbursts, the quality and continuity of their seismic data, and their employment of dedicated ground control personnel over the time period covered by this study. This has ensured continuity in good ground control practice. Complete information on rockbursts that occurred at the three mines over eight to 14 years was collected (Table 1). This resulted in a rockburst database that comprised 209 seismic events and the resulting damage to 324 mine openings. Mine A, being the deepest and the most seismically-active of the three mines, has been the primary site of interest throughout this study. All three mines use variations of open stoping as mining methods. Mine $\mathrm{C}$, however, employs primarily variations of the cut-and-fill method.

Table 1 Rockburst case studies database

\begin{tabular}{lcccc}
\hline & Mine A & Mine B & Mine C & Total \\
\hline Time frame & $2000-2013$ & $2004-2013$ & $2006-2013$ & - \\
Seismic events that resulted in damage & 123 & 18 & 68 & 209 \\
$\begin{array}{l}\text { Locations of damage to the rock mass } \\
\text { or ground support }\end{array}$ & 184 & 35 & 105 & 324 \\
Primary mining method & & & & \\
Depth range $(m)$ & Open stoping & Open stoping & Cut-an- fill & \\
\hline
\end{tabular}

The collected rockburst information was reviewed, validated, and organised into a comprehensive database. The details of the collected data and the validation process have been reported by Morissette et al. (2012). This was a comprehensive process that included an analysis of reported events, seismicity, ground support data, site inspections and numerical modelling. In the rockburst database, the information was organised as predictor and response variables. Predictor variables implied the characterisation of conditions associated with seismicity, the excavation (stress, rock mass quality and geological structures, and excavation's dimensions), or ground support. Response variables were reflective of the ground support performance, as a result of the imposed dynamic load characterised by the predictor variables. Some of the predictor variables were used for defining the recommended location of enhanced support as well as the timing of installation. The entire dataset was used in order to conduct a multi-variate statistical analysis of ground support performance. This analysis resulted in clustering rockburst events based on data similitude. Ground support performance was assessed within rockburst clusters that were characterised based on excavation dimensions and stress levels.

\section{$3 \quad$ Transitioning from static to dynamic support}

The evolution of ground support systems to respond to changes as mining progresses to higher stress environments is a challenge faced by several operations. This is a complex decision process that involves both technical and strategic interventions. A series of case studies of successful strategies in managing the transition to dynamic support have been reported by Morissette et al. (2014b).

In mines with a long history of monitoring seismicity, it is not unusual to observe changes and updates in the employed seismic systems. Consequently, for the rockburst database, adjustments to magnitude data were 
performed based on a calibration of the local seismic systems at Mines A, B, and C, with respect to the Nuttli magnitude scale $\left(M_{N}\right)$ reported by the Geological Survey of Canada (Morissette et al. 2014a). This calibration aimed at ensuring comparability amongst magnitude data collected from different mine sites.

Given the quantity and quality of the collected seismic data, it is possible to employ the complete seismic event records to assess the probability of a seismic event to result in a rockburst. An example of this approach is presented in Figure 1 for Mine A. This was estimated by calculating the ratios of the number of rockburst to number of seismic events of a given magnitude. The ratios were calculated by considering all rockbursts, rockbursts that generated more than 10 tonnes of displaced material within the mine, and those that generated more than 100 tonnes of damage.

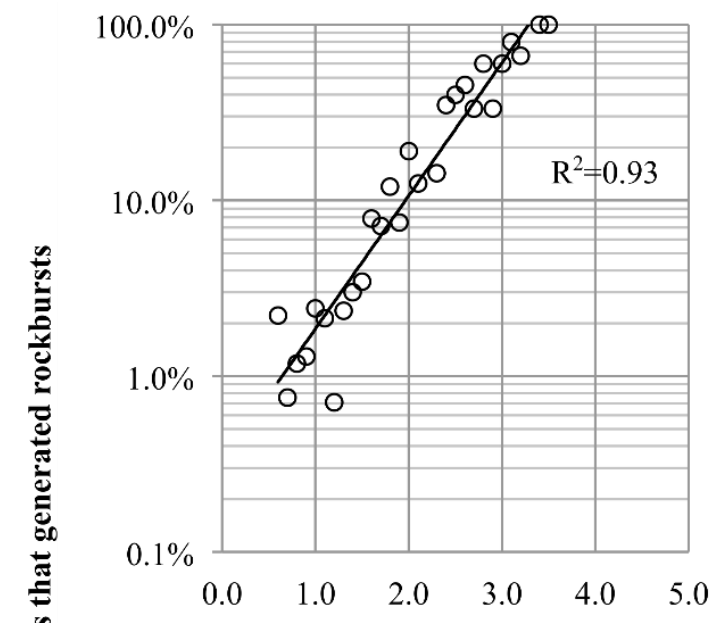

(a)

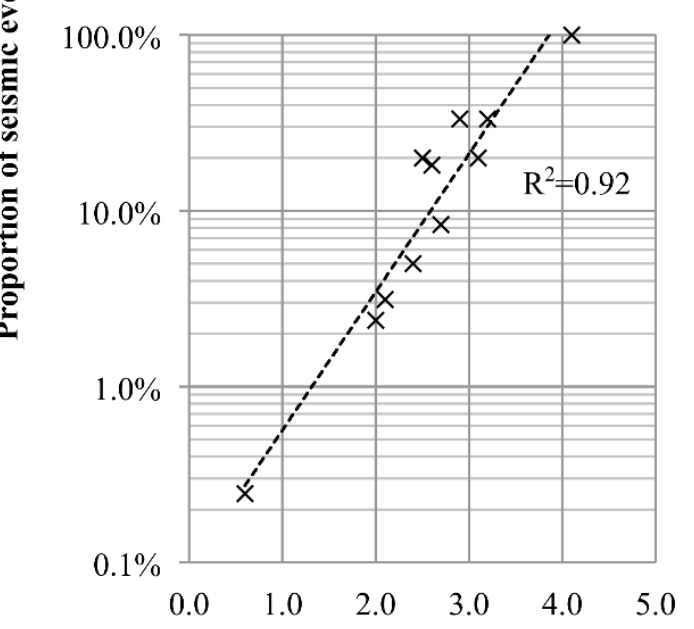

(c)

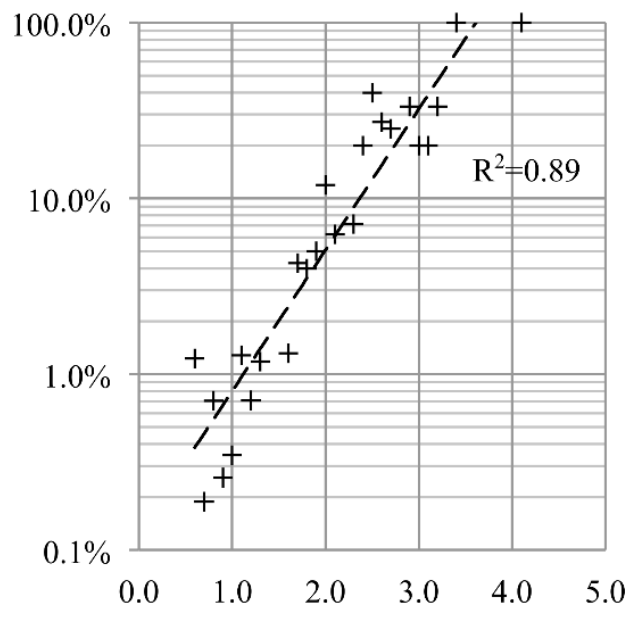

(b)

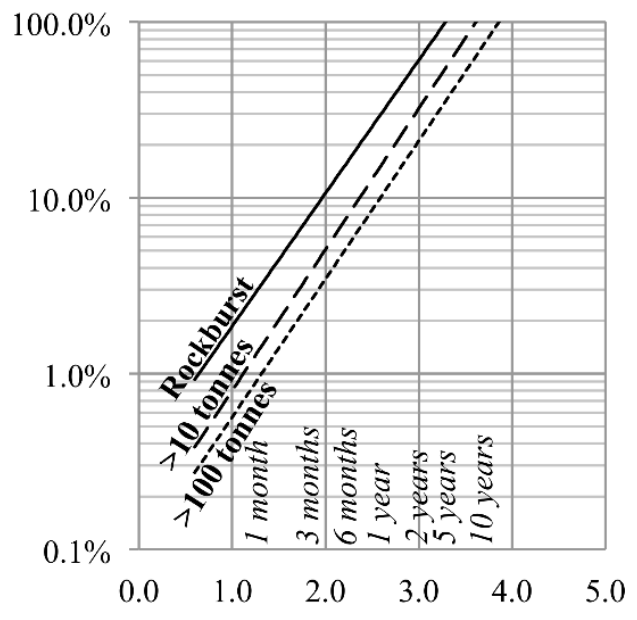

(d)

Adjusted event magnitude (Nuttli)

Figure 1 Estimated probability of a seismic event of a given magnitude to result in: (a) a rockburst; (b) a rockburst with more than 10 tonnes of displaced material within the mine; and, (c) a rockburst with more than 100 tonnes of displaced material within the mine. The probability lines for the three levels of damage severity are plotted in (d)

The regression lines (Figure 1$)$ are characterised by a very good fit $\left(0.89<R^{2}<0.93\right)$ and are interpreted as the estimated probability of a seismic event of a given magnitude to result in damage of a given severity. Given the time-continuity in the collected seismic and rockburst data, it was further possible to assess the typical return period of large magnitude seismic events (Figure $1(\mathrm{~d})$ ). Combining the probability of rockburst, and the return period of seismic events, provided a practical tool to assess the seismic risk depending on the service life of excavations at Mine A. 
The rockburst probability lines have practical applications for characterising the increase in the level of risk associated with an increase in event magnitude within a mine, or area of a mine. For support design purposes, magnitude thresholds can be identified using Figure 1 and further used to assess the geospatial distribution of seismic events that presents a justifiable level of risk on ground support integrity and excavation stability. Based on this guideline, a $\mathrm{M}_{N} 1.6$ event has a $5 \%$ probability of generating a rockburst and a $2.5 \%$ probability of resulting in more than 10 tonnes of damage. Alternately, a $\mathrm{M}_{\mathrm{N}} 2.0$ event has a $10 \%$ probability of generating a rockburst and a $5 \%$ probability of resulting in more than 10 tonnes of damage. The $M_{N} 1.6$ to $M_{N} 2.0$ range is interpreted as a transition zone, in which it is recommended for seismically-active mines to implement ground support strategies specifically designed to mitigate rockbursts.

An example of the performance of surface support under moderate seismic conditions, is illustrated by the following histogram (Figure 2), which represents the cumulative number of rockbursts in relation to the magnitude. Rockbursts were filtered based on the employed surface support. It is observed that rockbursts begin to occur in a regular manner under much lower magnitudes for ground support systems comprising mesh as opposed to mesh-reinforced shotcrete. This chart demonstrates that using a strong and stiff surface support element can effectively contribute in mitigating small magnitude seismic events up to $M_{N} 1.5$. Those events are typically associated with self-initiated rockbursts and the seismic source mechanism is often interpreted as strainburst. For $M_{N} 1.6$ or greater, rockbursts have occurred at a similar rate regardless of the employed primary surface support. This result suggests that beyond this magnitude threshold, dynamic-loading conditions cannot be managed only by increasing the strength and stiffness of the surface support, therefore, justifying the introduction of yielding ground support elements.

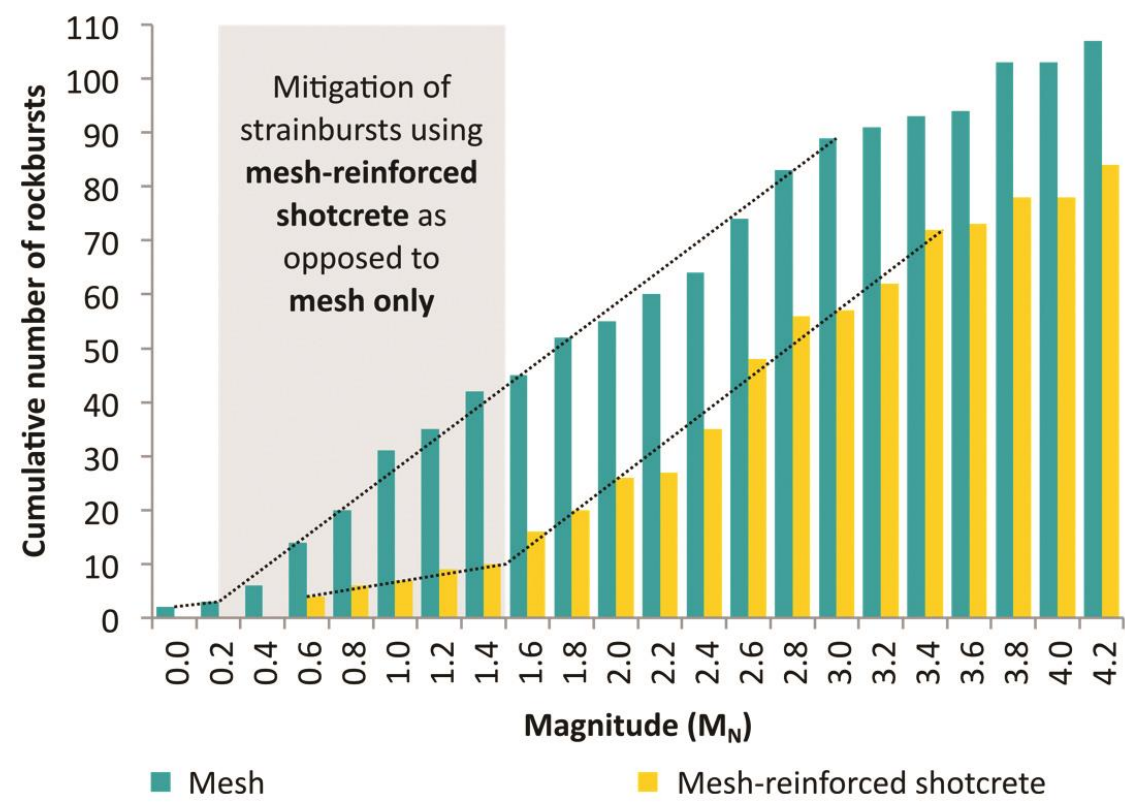

Figure 2 Cumulative number of rockbursts in relation to the magnitude in typical-size excavations ( 5 to $7 \mathrm{~m}$ span) for ground support systems comprising mesh or mesh-reinforced shotcrete

\section{$4 \quad$ Zoning of burst-prone mining areas}

Useful insights on mine locations where rockbursts can be anticipated can be gained by a careful review of the estimated level of ground motion and mining-induced stresses. This information has practical implications in targeting mining areas for the implementations of dynamic ground support strategies.

\subsection{Ground motion level}

The peak particle velocity is a convenient way to represent two important parameters in the assessment of the dynamic-load demand on ground support systems: 1) the magnitude and 2) the distance between the excavation and the seismic event, which is typically represented as a point-source in seismic monitoring 
systems designed for mining applications. Important limitations of the ppv scaling laws include the assumption of a spherical radiation pattern and the disregard of seismic-wave reflection and refraction phenomena. This can lead to important discrepancies between actual and predicted levels of ground motion (Potvin \& Wesseloo 2013; Milev et al. 2002). Furthermore, the amplification of seismic waves in the vicinity of excavations cannot be quantified reliably (Durrheim 2012).

For the particular database in this investigation, the ppv scaling law developed by Hedley (1992) was deemed appropriate for the analysis as it was based on data collected in underground mines from Elliot Lake and Sudbury, in Ontario, Canada. Furthermore, it employs $M_{N}$ and is based on a best fit of the collected seismic data, as opposed to an upper limit regression, which is employed in other guidelines (Kaiser et al. 1996).

The scaling law from Hedley (1992) managed to capture the variability in the rockburst data since rockbursts were distributed along a similar trend (Figure 3). The ppv percentiles allow for a relative comparison of the level of ground motion imposed on ground support systems under dynamic-loading conditions. The 10th and 90th ppv percentiles indicate that the majority of damage to ground support and mine excavations were triggered by ppv levels ranging from 29 to $725 \mathrm{~mm} / \mathrm{s}$.

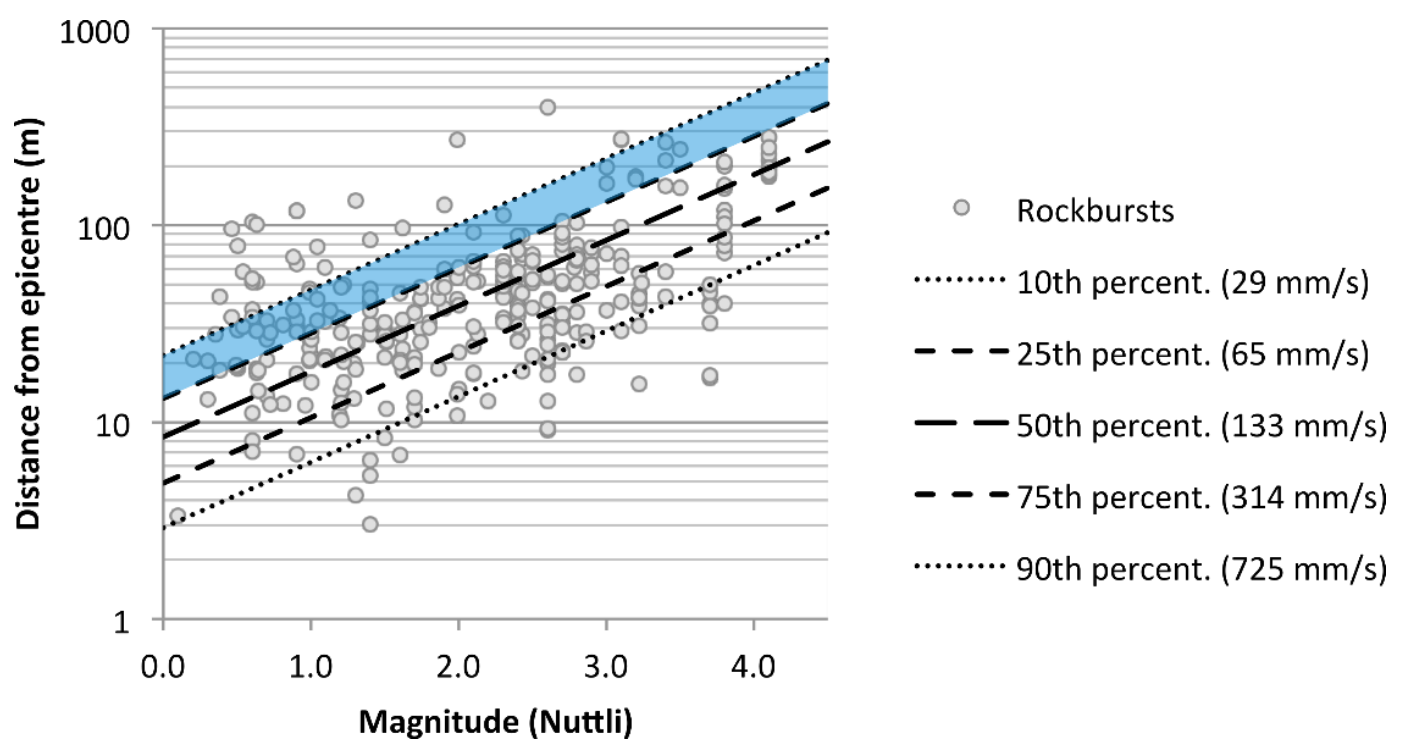

Figure 3 Levels of ground motion estimated based on the magnitude and distance from seismic event using the scaling law proposed by Hedley (1992), for rockbursts at Mines A, B, and C

A ppv range for rockburst initiation is determined using the 10th and 25th ppv percentiles ( 29 and $65 \mathrm{~mm} / \mathrm{s}$ ). This range coincides with Hedley's $50 \mathrm{~mm} / \mathrm{s}$ ppv threshold for falls of loose grounds. The ppv range for rockburst initiation can have practical implication in targeting areas where support degradation might have occurred as a result of mine seismicity. For ground support design, Figure 3 can be a useful tool in a context where seismicity is associated with a specific geological structure, such as a fault or a dyke. Based on the level of seismic hazard, i.e. the largest anticipated magnitude (Hudyma 2008), related to such seismically-active feature, a radius of influence within which ground support should be enhanced can be identified.

In practice, a mine could decide on designing the ground support based on the largest anticipated seismic event, related to a geological structure, using the corresponding magnitude threshold. This value can be linked to a specific ppv percentile as a design criterion. For example, for a design $M_{N} 2.5$ event and the 25th ppv percentile in Figure 3, this approach would result in a recommendation to enhance the ground support within $90 \mathrm{~m}$ from the seismically-active structure.

\subsection{Mining-induced stress level}

The proposed radius of influence, derived from the application of ppv scaling laws, can be a very practical tool but its applicability might also be limited. Determining the location of a design seismic event is a complicated assignment. The location and timing of the implementation of a dynamic ground support 
strategy can be defined using well calibrated stress analyses models. A case study of this approach has been documented by Morissette et al. (2016).

In addition to comparing long-term trends in mining-induced stresses and seismicity, mining-induced stresses at the location and the time of occurrence for each rockburst reported in the database was assessed. This task implied that, in the employed numerical models of Mines $A, B$, and C, the mine geometry was accurately represented for the time of occurrence of each rockburst. Figure 4 presents the mining-induced stresses at the time and location of each rockburst reported in the database. Severity of damage was represented by colour-coding rockbursts based on the rock damage scale (RDS), developed by Kaiser et al. (1992), (Morissette et al. 2012).

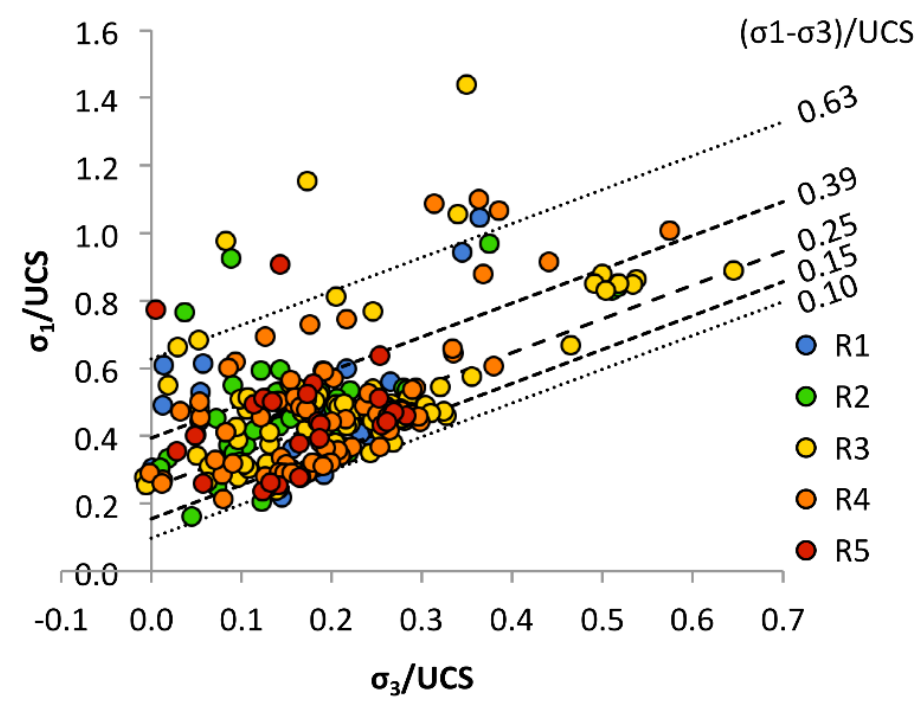

Figure 4 Normalised differential stress and severity of damage, interpreted using the RDS (Kaiser et al. 1992; Morissette et al. 2012), for the rockbursts that occurred at Mines A, B, and C

In the proposed ground support strategy, the potential for rockburst is assessed using the differential stress normalised to the uniaxial compressive strength: $\left(\sigma_{1}-\sigma_{3}\right) /$ UCS. In the case where no seismically-active structure is reported within $15 \mathrm{~m}$ from a mine excavation, it is recommended to implement a dynamic ground support strategy in areas where the normalised differential stress is expected to reach or exceed 0.25 . This corresponds approximately to the median value in the rockburst data. If structures are reported within $15 \mathrm{~m}$ from the excavation, a normalised differential stress threshold of 0.20 should apply. This corresponds to approximately the 25th percentile value. In both cases, enhanced ground support should be installed prior to the differential stresses reaching $20 \%$ of the UCS.

Numerical modelling of the stress conditions at each rockburst site, using a numerical model calibrated with mine seismicity, demonstrated that the normalised differential stress thresholds for rockburst occurrence are very similar to the thresholds associated with the occurrence of seismic events (Morissette et al. 2016). This observation suggests that rockbursts are susceptible of occurring in areas where the stress conditions can trigger seismic activity. This might be over-estimated if it is not tempered by considering the role of the installed ground support system. In practice, different levels of enhanced ground support can be prescribed in order to mitigate dynamic loads imposed under various ranges of stress conditions.

\section{$5 \quad$ Assessment of ground support performance}

In the rockburst database, both the type of reinforcement elements installed at the damage location and the installation pattern were reported. Information from static (pull) and dynamic (drop) tests was used in order to calculate the conceptual load-bearing and energy-absorption capacities, per square metre, of each configuration of reinforcement elements. For individual reinforcement elements, the load capacity 
corresponded to the tensile strength or maximum load, whereas energy capacity corresponded to the maximum impact energy (Table 2). The conceptual capacities of reinforcement configurations installed in excavations' back and walls and the different reinforcement combinations are listed in Figure 5.

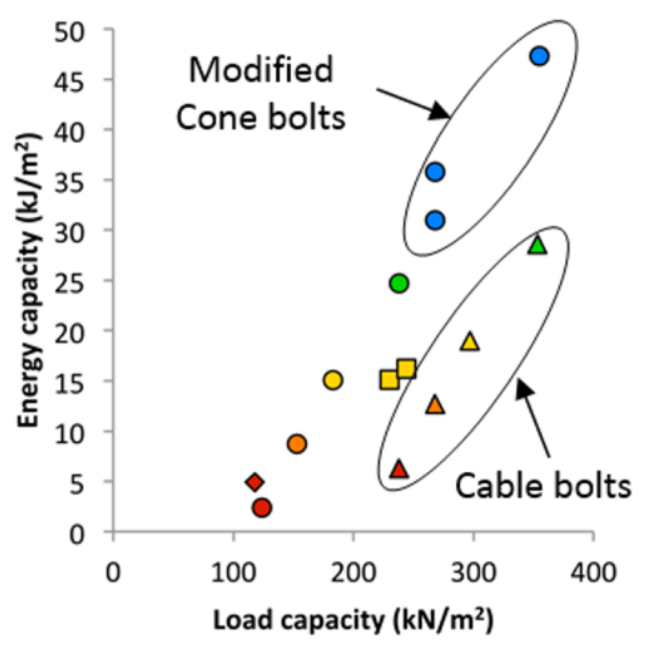

(a)

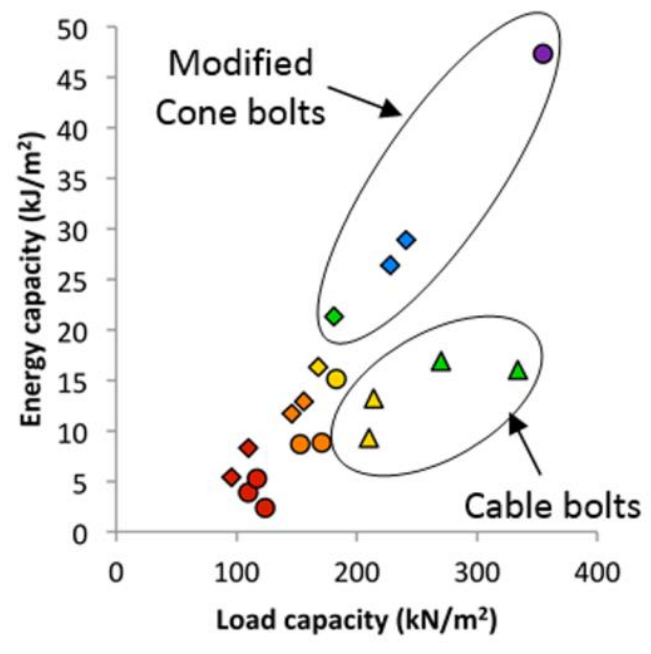

(b)

\begin{tabular}{|c|c|c|c|c|}
\hline B1 & $\begin{array}{l}\text { - } \quad \text { Mechanical bolts } \\
\quad \text { Swellex PM12 }\end{array}$ & W1 & & $\begin{array}{l}\text { Mechanical bolts; or } \\
\text { Mechanical bolts and } 35 \text { or } 39 \mathrm{~mm} \text { friction sets }\end{array}$ \\
\hline B2 & Mechanical bolts, $2^{\text {nd }}$ pass of cables & $\mathrm{W} 2$ & - & 35 or $39 \mathrm{~mm}$ friction sets \\
\hline B3 & Mechanical bolts and rebars & W3 & $\bullet$ & $\begin{array}{l}\text { Mechanical bolts and rebars; or } \\
\text { Mechanical bolts, } 2^{\text {nd }} \text { pass of Swellex MN12 }\end{array}$ \\
\hline B4 & $\begin{array}{l}\text { Mechanical bolts and rebars, } 2^{\text {nd }} \text { pass of } \\
\text { cables }\end{array}$ & W4 & 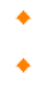 & $\begin{array}{l}39 \mathrm{~mm} \text { friction sets and rebars; or } \\
46 \mathrm{~mm} \text { friction sets }\end{array}$ \\
\hline B5 & Rebars & W5 & 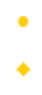 & $\begin{array}{l}\text { Rebars; or } \\
39 \mathrm{~mm} \text { friction sets, } 2^{\text {nd }} \text { pass of Swellex MN12 }\end{array}$ \\
\hline B6 & $\begin{array}{l}\text { Mechanical bolts and rebars, } 2^{\text {nd }} \text { pass of } \\
\text { rebars or Mechanical bolts and rebars, } \\
2^{\text {nd }} \text { pass of FS- } 46\end{array}$ & W6 & $\Delta$ & $35 \mathrm{~mm}$ friction sets, $2^{\text {nd }}$ pass of cables \\
\hline B7 & Rebars, $2^{\text {nd }}$ pass of cables & W7 & $\bullet$ & $35 \mathrm{~mm}$ friction sets, $2^{\text {nd }}$ pass of $\mathrm{MCB}$ \\
\hline B8 & $\begin{array}{l}\text { Mechanical bolts and rebars, } 2^{\text {nd }} \text { pass of } \\
\text { MCB }\end{array}$ & W8 & $\Delta$ & $\begin{array}{l}46 \mathrm{~mm} \text { frictions sets, } 2^{\text {nd }} \text { pass of cables; or } \\
39 \mathrm{~mm} \text { friction sets, tight cable-bolt pattern }\end{array}$ \\
\hline B9 & $\begin{array}{l}\text { Mechanical bolts and rebars, } 2^{\text {nd }} \text { pass of } \\
\text { MCB and cables }\end{array}$ & W9 & $\bullet$ & $46 \mathrm{~mm}$ frictions sets, $2^{\text {nd }}$ pass of $\mathrm{MCB}$ \\
\hline 10 & Rebars and MCB & W10 & $\bullet$ & Rebars and $\mathrm{MCB}$ \\
\hline
\end{tabular}

Figure 5 Load-bearing and energy-absorption capacities of combinations of reinforcement elements installed in: (a) the back; and, (b) the walls of mine openings 
Table 2 Load and energy-absorption capacities of reinforcement elements employed in classifying ground support systems. Data compiled from multiple sources

\begin{tabular}{llllll}
\hline $\begin{array}{l}\text { Reinforcement } \\
\text { elements }\end{array}$ & $\begin{array}{l}\text { Load } \\
\text { capacity } \\
\text { (kN) }\end{array}$ & $\begin{array}{l}\text { Energy } \\
\text { capacity } \\
\text { (kJ) }\end{array}$ & $\begin{array}{l}\text { Reinforcement } \\
\text { elements }\end{array}$ & $\begin{array}{l}\text { Load } \\
\text { capacity } \\
\text { (kN) }\end{array}$ & $\begin{array}{l}\text { Energy } \\
\text { capacity } \\
\text { (kJ) }\end{array}$ \\
\hline Mechanical bolt & 115 & 2.2 & Swellex Mn12 bolt & 110 & 15 \\
\hline Resin-grouted rebar & 170 & 14 & $35 \mathrm{~mm}$ friction set & 89 & 5.0 \\
\hline Modified conebolt & 160 & 30 & $39 \mathrm{~mm}$ friction set & 102 & 7.7 \\
\hline D-bolt $(20 \mathrm{~mm})$ & 210 & 45 & $46 \mathrm{~mm}$ friction set & 145 & 15 \\
\hline D-bolt $(22 \mathrm{~mm})$ & 250 & 56 & Plain strand cable & 265 & 18 \\
\hline Swellex PM12 bolt & 110 & 4.6 & & & \\
\hline
\end{tabular}

The assessment of ground support performance, under dynamic-loading conditions, was undertaken for similar excavation conditions. Similitudes in the rockburst data were identified using the principal component analysis technique and a three-component model was fit to the data. The first principal component captured variations in the seismicity-related parameters: correlations between magnitude, distance from the seismic source, and the interpreted seismic source mechanism were identified. The second and third principal components captured variations in the excavation conditions (rock mass quality, depth, normalised differential stress, span) and reinforcement length. Clustering of the collected rockburst data was achieved using the Ward's method (Ward 1963), based on the scores on the plane defined by the second and third principal components. Six groups of rockbursts were identified (Figure 6(a)). An important differentiation between these groups is the length of the excavation span, and the normalised major principal stress (Figure 6(b)). The most populated rockburst groups are Group 2 and Group 6 with 56 and 139 rockbursts, respectively. These are representative of a typical drift size and moderate to very high stress conditions and are the focus of this paper.

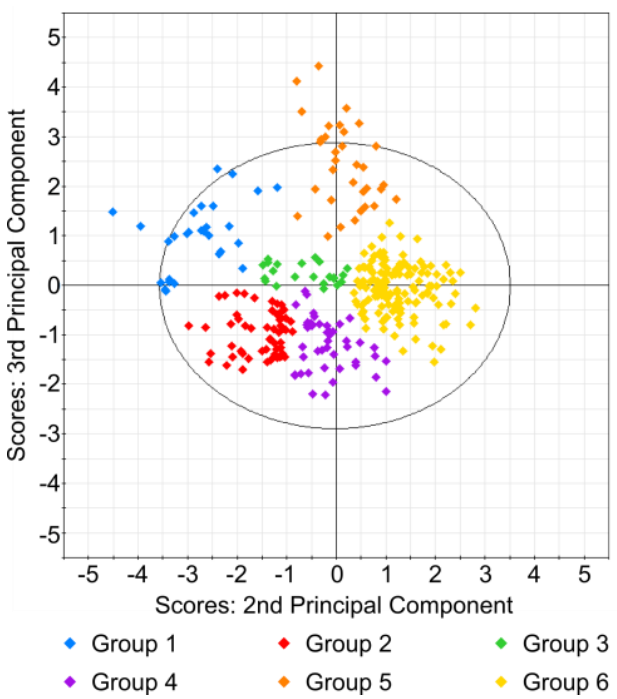

(a)

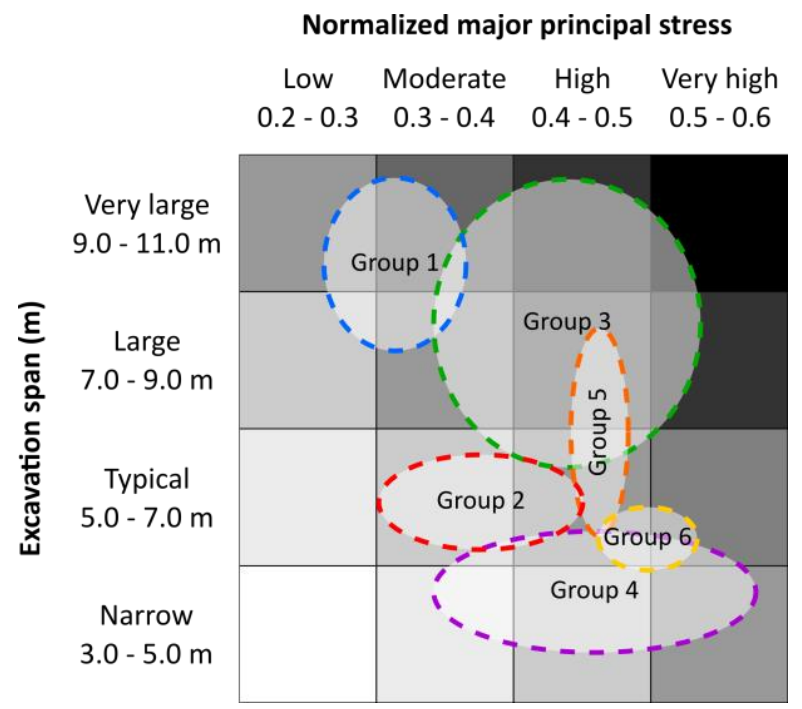

(b)

Figure 6 Identification of six rockburst groups based on the 2nd and 3rd principal components

In conducting passive monitoring of ground support performance under dynamic-loading conditions, the severity of damage to ground support systems was characterised using the support damage scale from Kaiser et al. (1992). Mikula (2012) simplified this damage classification by commenting on whether the level of ground support degradation was acceptable (0-2), tolerable (3), or inacceptable (4-5). In referring to 
acceptable or tolerable levels of support damage, it is implied that the displaced material has been contained by the support, for the most part. The precise distinction between acceptable and tolerable damage, however, is quite subjective. These levels of damage are interpreted as successful performance of the support, regardless of the possible need for rehabilitation. Intolerable damage implies that the safety of mining equipment or personnel could have been compromised by the support not being capable of containing the displaced material. Such levels of damage correspond to the unsuccessful performance of the support and the need for rehabilitation is certain.

The influence of the interaction between the rock reinforcement and surface support that constitute a ground support system was also investigated. Figure 7 illustrates the performance of ground support systems installed in the back for rockburst Groups 2 and 6. The ppv-performance thresholds (red dashed lines) are based on the dynamic-loading component, represented by the seismic event magnitude and the distance between the event and the damage. The charts with a white background represent surface support that consisted of welded wire-mesh, whereas the grey background represents support systems that comprised mesh-reinforced shotcrete. In rockburst Group 6, a distinction is made based on whether the ground support was stiff (Figure 7(b)) or enhanced using yielding reinforcement elements (Figure 7(c)). In order to establish the range of dynamic conditions encountered in deep underground mines, rockburst data are presented along with the 10th and 90th ppv percentiles described in Figure 3.
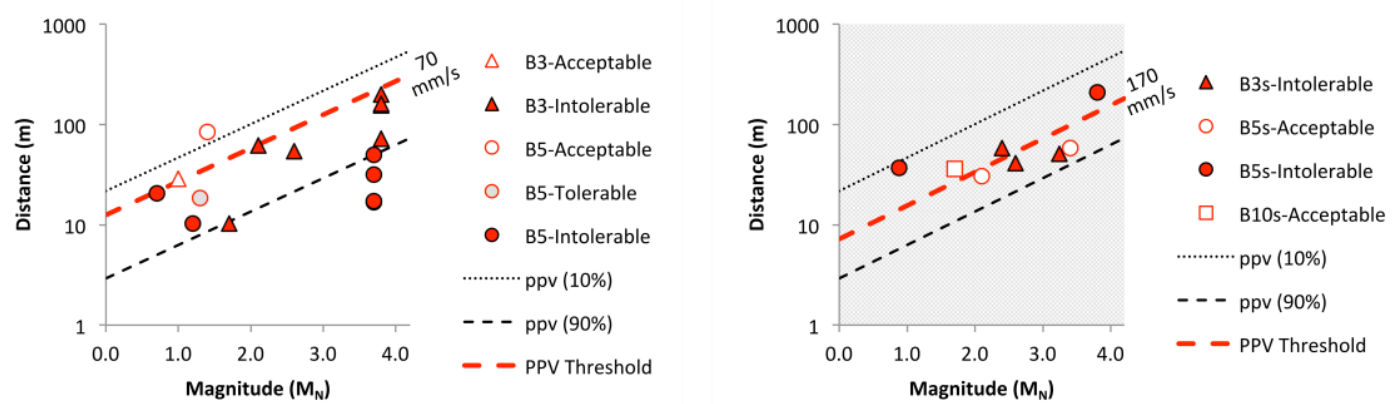

(a)
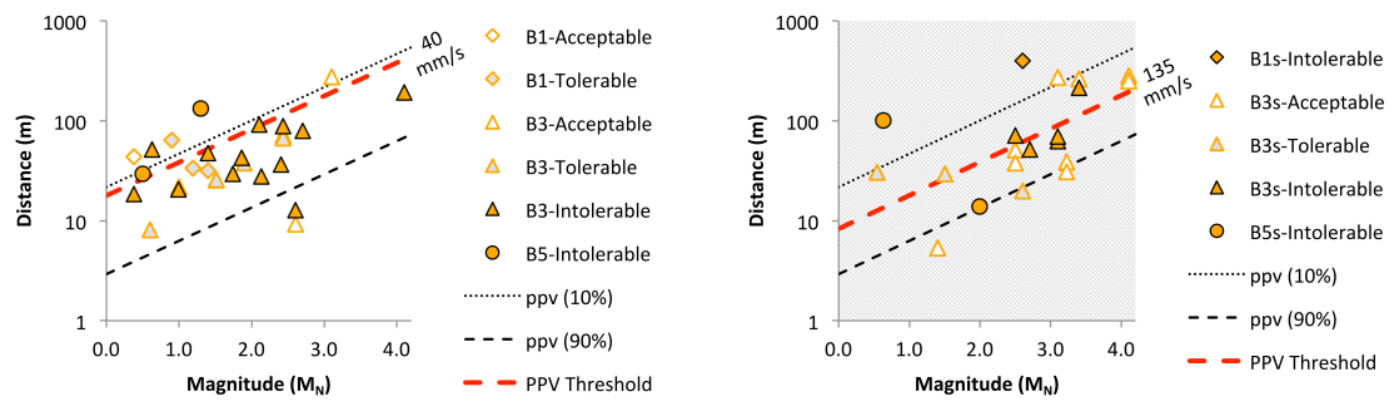

(b)
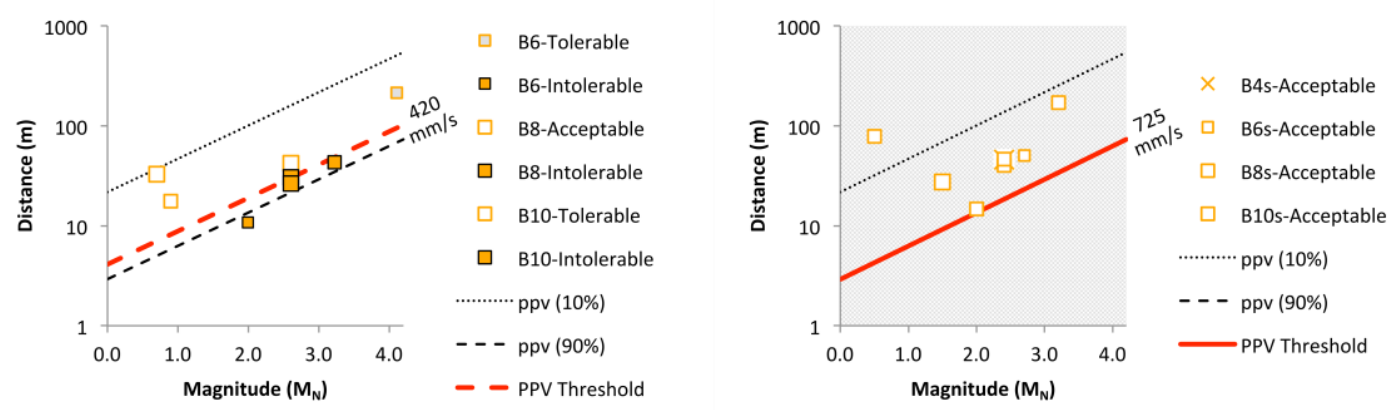

(c)

Figure 7 Performance of stiff ground support systems in rockburst: Group 2 (a) and Group 6 (b); and, (c) yielding ground support systems in Group 6 
It is observed by comparing Figure 7(a) and Figure 7(b) that similar stiff ground support systems reached failure under lower dynamic-load levels while being exposed to higher stress conditions. A comparison between Figures $7(b)$ and 7 (c) demonstrates the significant gain in support performance is achieved using yielding ground support elements. Based on these visual assessments, ppv-performance thresholds are presented in the following section as part of ground support selection guidelines.

\section{$6 \quad$ Ground support selection guidelines}

Although it is not possible to adequately quantify the dynamic-load demand on ground support systems, in terms of energy per surface unit, it is clear that the span of mine openings, the stress conditions, and the level of seismic loading ultimately play a role in the support performance. Using the collected rockburst data, support-performance thresholds specific to categories of ground support systems were quantified in terms of a conceptual ppv. For the back, those support-performance thresholds were defined with reference to the span of mine openings and stress conditions. The performance thresholds of ground support systems are presented in Table 3, providing information on the employed reinforcement and surface support elements and conceptual load-bearing and energy-absorption capacities.

Table 3 PPV-performance thresholds of ground support systems installed in the back

\begin{tabular}{|c|c|c|c|c|c|c|}
\hline \multirow[t]{2}{*}{$\begin{array}{l}\text { Span } \\
\text { (m) }\end{array}$} & \multirow[t]{2}{*}{$\sigma_{1} /$ UCS } & \multicolumn{2}{|c|}{ Ground support systems } & \multicolumn{2}{|c|}{$\begin{array}{l}\text { Conceptual } \\
\text { reinforcement } \\
\text { capacity }\end{array}$} & \multirow{2}{*}{$\begin{array}{l}\text { PPV-performance } \\
\text { thresholds } \\
(\mathrm{mm} / \mathrm{s})\end{array}$} \\
\hline & & Reinforcement & Surface support & $\begin{array}{l}\text { Load } \\
\left(\mathrm{kN} / \mathrm{m}^{2}\right)\end{array}$ & $\begin{array}{l}\text { Energy } \\
\left(\mathrm{kJ} / \mathrm{m}^{2}\right)\end{array}$ & \\
\hline \multirow{4}{*}{$>7.0$} & \multirow[b]{2}{*}{$0.2-0.4$} & \multirow{2}{*}{$\begin{array}{l}\text { 1st pass rebars } \\
2 \text { nd pass cables }\end{array}$} & Welded-wire mesh (B7) & 300 & 19 & 150 \\
\hline & & & $\begin{array}{l}\text { Mesh-reinforced } \\
\text { shotcrete (B7s) }\end{array}$ & 300 & 19 & 725 \\
\hline & \multirow[b]{2}{*}{$0.4-0.5$} & $\begin{array}{l}\text { 1st pass rebars } \\
2 \text { nd pass cables }\end{array}$ & $\begin{array}{l}\text { Mesh-reinforced } \\
\text { shotcrete (B7s) }\end{array}$ & 300 & 19 & 350 \\
\hline & & $\begin{array}{l}\text { 1st pass rebars } \\
\text { 2nd pass cables } \\
\text { and } \mathrm{MCB}\end{array}$ & $\begin{array}{l}\text { Mesh-reinforced } \\
\text { shotcrete (B9s) }\end{array}$ & 380 & 35 & 725 \\
\hline \multirow{6}{*}{$5.0-7.0$} & \multirow[b]{2}{*}{$0.3-0.4$} & \multirow[b]{2}{*}{ Rebars } & Welded-wire mesh (B5) & 180 & 15 & 70 \\
\hline & & & $\begin{array}{l}\text { Mesh-reinforced } \\
\text { shotcrete (B5s) }\end{array}$ & 180 & 15 & 170 \\
\hline & \multirow[b]{2}{*}{$0.4-0.6$} & \multirow[b]{2}{*}{ Rebars } & Welded-wire mesh (B5) & 180 & 15 & 40 \\
\hline & & & $\begin{array}{l}\text { Mesh-reinforced } \\
\text { shotcrete (B5s) }\end{array}$ & 180 & 15 & 135 \\
\hline & \multirow{2}{*}{$0.4-0.6$} & \multirow{2}{*}{$\begin{array}{l}\text { 1st pass rebars } \\
2 \text { nd pass } \mathrm{MCB} \\
\text { or one-pass } \\
\text { rebars/MCB }\end{array}$} & $\begin{array}{l}\text { Welded-wire mesh } \\
\text { (B8/B10) }\end{array}$ & 270 & $31-36$ & 420 \\
\hline & & & $\begin{array}{l}\text { Mesh-reinforced } \\
\text { shotcrete (B8s/B10s) }\end{array}$ & 270 & $31-36$ & 725 \\
\hline$<5.0$ & $0.4-0.6$ & Rebars & Welded-wire mesh (B5) & 180 & 15 & 65 \\
\hline
\end{tabular}

$\mathrm{MCB}=$ modified conebolt. 
The guidelines indicate the advantages of using cable bolts in the back of large mine openings (span $>7.0 \mathrm{~m}$ ) and the benefits of applying shotcrete between a first pass of resin rebars and a second pass of cable bolts. Under low to moderate stress environments, the application of shotcrete improved the ppv performance threshold from 150 to $725 \mathrm{~mm} / \mathrm{s}$. The largest threshold value attributed to the successful performance of ground support systems was $725 \mathrm{~mm} / \mathrm{s}$, the 90th percentile of the ppv estimated in the collected rockburst data. The improvements to the performance of the ground support systems, attributed to shotcrete, however, are limited under high stress conditions. The ppv-performance threshold of support systems B7s was reduced from 725 to $350 \mathrm{~mm} / \mathrm{s}$ under major principal stress levels corresponding to 0.4 to 0.5 times the rock UCS. The addition of yielding reinforcement elements in the second pass, as part of support system B9s, resulted in improved support performance under high stress. The ppv-performance thresholds of ground support systems installed in the walls of mine openings are presented in Table 4.

Table 4 PPV-performance threshold of detailed ground support systems installed in the walls

\begin{tabular}{|c|c|c|c|c|c|}
\hline \multirow[b]{2}{*}{$\sigma_{1} /$ UCS } & \multicolumn{2}{|c|}{ Ground support systems } & \multicolumn{2}{|c|}{$\begin{array}{l}\text { Conceptual } \\
\text { reinforcement capacity }\end{array}$} & \multirow{2}{*}{$\begin{array}{l}\text { PPV-performance } \\
\text { thresholds } \\
(\mathrm{mm} / \mathrm{s})\end{array}$} \\
\hline & Reinforcement & Surface support & $\begin{array}{l}\text { Load } \\
\left(\mathrm{kN} / \mathrm{m}^{2}\right)\end{array}$ & $\begin{array}{l}\text { Energy } \\
\left(\mathrm{kJ} / \mathrm{m}^{2}\right)\end{array}$ & \\
\hline \multirow{8}{*}{$0.2-0.4$} & \multirow[b]{2}{*}{ Mechanical bolts } & Welded-wire mesh (W1) & $110-124$ & $2-5$ & 90 \\
\hline & & $\begin{array}{l}\text { Mesh-reinforced } \\
\text { shotcrete (W1s) }\end{array}$ & $110-124$ & $2-5$ & 90 \\
\hline & \multirow[b]{2}{*}{ FS-35/39 } & Welded-wire mesh (W2) & $96-110$ & $5-8$ & 170 \\
\hline & & $\begin{array}{l}\text { Mesh-reinforced } \\
\text { shotcrete (W2s) }\end{array}$ & $96-110$ & $5-8$ & 170 \\
\hline & \multirow[b]{2}{*}{ FS-46 } & Welded-wire mesh (W4) & 156 & 12 & 500 \\
\hline & & $\begin{array}{l}\text { Mesh-reinforced } \\
\text { shotcrete (W4s) }\end{array}$ & 156 & 12 & 500 \\
\hline & $\begin{array}{l}\text { FS-39 and Swellex } \\
\text { Mn12 }\end{array}$ & $\begin{array}{l}\text { Mesh over fibercrete } \\
\text { (W5s) }\end{array}$ & 168 & 16 & 725 \\
\hline & $\begin{array}{l}\text { 1st pass FS-46 } \\
\text { 2nd pass } M C B\end{array}$ & $\begin{array}{l}\text { Mesh-reinforced } \\
\text { shotcrete (W9s) }\end{array}$ & $230-240$ & $26-28$ & 725 \\
\hline \multirow{6}{*}{$0.4-0.6$} & \multirow[b]{2}{*}{ FS-35/39 } & Welded-wire mesh (W2) & $96-110$ & $5-8$ & 50 \\
\hline & & $\begin{array}{l}\text { Mesh-reinforced } \\
\text { shotcrete (W2s) }\end{array}$ & $96-110$ & $5-8$ & 100 \\
\hline & \multirow[b]{2}{*}{ FS-46 } & Welded-wire mesh (W4) & 156 & 12 & 90 \\
\hline & & $\begin{array}{l}\text { Mesh-reinforced } \\
\text { shotcrete (W4s) }\end{array}$ & 156 & 12 & 300 \\
\hline & \multirow{2}{*}{$\begin{array}{l}\text { 1st pass FS- } 46 \\
\text { 2nd pass MCB or } \\
\text { cables }\end{array}$} & $\begin{array}{l}\text { Welded-wire mesh } \\
\text { (W8/W9) }\end{array}$ & $228-270$ & $16-28$ & 400 \\
\hline & & $\begin{array}{l}\text { Mesh-reinforced } \\
\text { shotcrete (W8s/W9s) }\end{array}$ & $228-270$ & $16-28$ & 400 \\
\hline
\end{tabular}

$\mathrm{MCB}=$ modified conebolt.

Mechanical bolts can be used in the walls under low to moderate stress conditions, however, their threshold of performance is relatively low. The performance improves when mechanical bolts are substituted by 35 or 
$39 \mathrm{~mm}$ friction sets in the support design and improves even further when $46 \mathrm{~mm}$ friction sets are employed. Under low to moderate stress conditions, shotcrete did not appear to raise the ppv-performance threshold of ground support systems that comprised only one pass of reinforcement. Consequently, supporting the walls using shotcrete is most likely unnecessary under such conditions. The highest ppv-performance threshold was obtained by support systems W5s and W9s. Based on the conceptual capacity, support systems W5s comprised either resin grouted rebars installed in conjunction with mesh-reinforced shotcrete or a FS-39 pattern installed in conjunction with mesh over a membrane of fibre-reinforced shotcrete and enhanced further by a second pass of Swellex Mn12 in conjunction with heavy-gauge straps. Although the conceptual load-bearing and energy-absorption capacities were similar, the two systems performed differently under dynamic loads, with the latter resulting in a $725 \mathrm{~mm} / \mathrm{s}$ performance threshold. This level of performance was matched by support system W9s, which consisted of a first pass of FS-46, mesh-reinforced shotcrete, and a second pass of straps and modified conebolt (MCB).

Shotcrete had a greater influence on the performance of ground support systems under high stress environments. In situations and locations where significant rock fracturing is caused by a high mining-induced stress environment, shotcrete appears to control dilation, which results in a better confinement around the bolts. The ppv-performance threshold of ground support systems in the walls was considerably reduced due to the higher stress environment. Nevertheless, there was still a clear advantage in using larger diameter and longer friction set bolts in the walls. The installation of cable bolts or MCB as part of a second pass contributed to increasing the ppv-performance threshold further.

\subsection{Example application of the ground support selection guidelines}

The application of the support selection tables is presented in a conceptual example. A haulage drive, $6 \mathrm{~m}$ wide, is to be supported in consideration of a design seismic event of a magnitude $\mathrm{M}_{N} 3.2$, which is anticipated at a $60 \mathrm{~m}$ distance from the tunnel. The excavation is under high stress conditions $\left(0.4 \leq \sigma_{1} /\right.$ UCS $\left.<0.5\right)$.

Figure 8(a) indicates that the demand imposed by the design $M_{N} 3.2$ event could be adequately managed by ground support systems B8 and B10 in the back. Hence, for the back of the tunnel, the recommended support system consists of either a diamond pattern of rebars and $\mathrm{MCB}$ or a first pass of rebars followed by a second pass of MCB and heavy-gauge straps. Reinforcement elements should be installed in conjunction with welded-wire mesh. The installation pattern should be designed in consideration of the required conceptual load-bearing and energy-absorption capacities of $270 \mathrm{kN} / \mathrm{m}^{2}$ and $31-36 \mathrm{~kJ} / \mathrm{m}^{2}$, respectively.

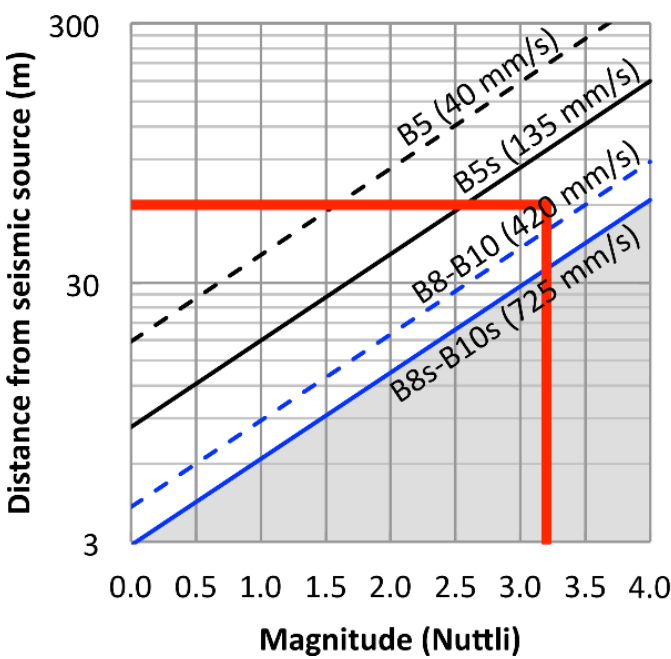

(a)

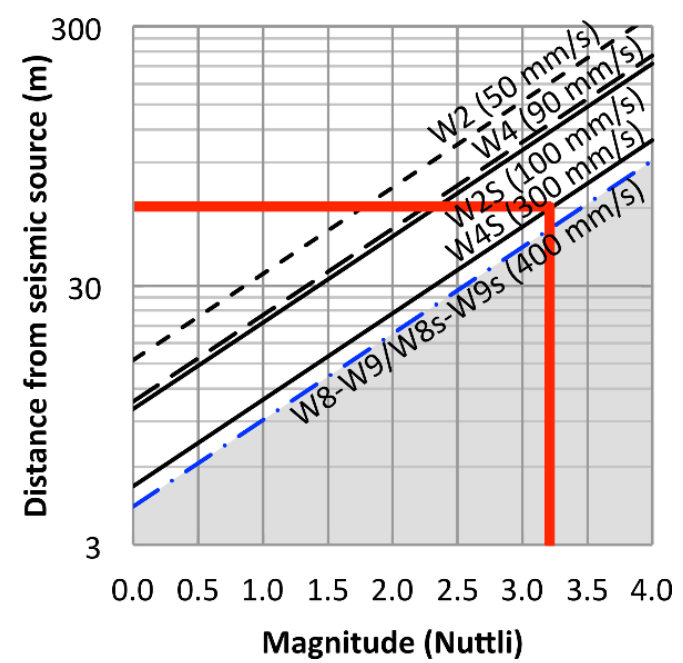

(b)

Figure 8 Application of the proposed support-selection guideline for: (a) the back; and, (b) the walls of a mine opening 
In the walls, the recommendation is to employ ground support W4s, W8(s) or W9(s) (Figure 8(b)). Based on these guidelines, it is justified to design a ground support system that comprises $46 \mathrm{~mm}$ friction sets, installed on a diamond pattern, in conjunction with welded wire mesh. A second pass of MCB is installed further, in conjunction with heavy-gauge mesh straps. The installation pattern should be designed in consideration of the required conceptual load-bearing and energy-absorption capacities of $228-270 \mathrm{kN} / \mathrm{m}^{2}$ and $16-28 \mathrm{~kJ} / \mathrm{m}^{2}$, respectively.

As mines become deeper, it is possible that the required ppv-performance thresholds exceed those of the support systems covered in this section. Those support systems reflected the ground support practice at Mines A, B, and C from 2000 to 2013. Under anticipated burst-prone conditions, the mines have typically relied on ground support systems that were a combination of stiff and yielding elements. MCB were often installed as a second pass, in conjunction with \#0 gauge straps, over a first pass of rebars, or mechanical bolts and rebars. Based on the collected rockburst data, such approach is applicable up to a ppv level of $725 \mathrm{~mm} / \mathrm{s}$ in the back of mine openings under high stress conditions. As the mine seismicity increases, it is anticipated to employ ground support systems that exceed this performance threshold.

\subsection{Exploring new ground support options}

Establishing a comprehensive database based on passive monitoring is an on-going process. At the same time, new ground support systems are becoming readily available and are subject to impact loading tests and field trials. It is possible to use this information and investigate how new bolts can potentially respond under dynamic conditions. An example of how this information can be used is provided with reference to a yielding bolt such as the D-bolt. The D-bolt is an energy-absorbing rockbolt, which consists of a smooth steel bar with anchors spaced along its length (Li 2012). The stretching mechanism promoted by the D-bolt results in a reinforcement element that is capable of absorbing high levels of kinetic energy while maintaining the resulting displacements under tolerable levels. The yield load, tensile strength, and maximum impact energy sustained by the 20 and $22 \mathrm{~mm}$ diameter D-bolts in laboratory tests were presented in Table 2.

The conceptual load-bearing and energy-absorption capacities of two patterns of D-Bolts are calculated using the tensile strength and the maximum impact energy. Those parameters are used to provide an ultimate capacity, which can further be compared to the capacity of other configurations of reinforcement elements presented in this section. The conceptual capacities of D-bolts' configurations are presented in Table 5. The bolting densities reflect a 3-2-3 pattern, i.e. eight bolts per $1.52 \times 3.35 \mathrm{~m}\left(5^{\prime} \times 11^{\prime}\right)$ mesh sheet, and a 4-3-4 pattern, i.e. 11 bolts per mesh sheet. A $0.30 \mathrm{~m}$ (1') overlap between mesh sheets is considered in the calculations.

Table 5 Conceptual load-bearing and energy-absorption capacities of two configurations of 20 and $22 \mathrm{~mm} \mathrm{D}$-bolts based on laboratory testing results

\begin{tabular}{|c|c|c|c|}
\hline & Bolting density & $\begin{array}{l}\text { Load capacity } \\
\left(\mathrm{kN} / \mathrm{m}^{2}\right)\end{array}$ & $\begin{array}{l}\text { Energy capacity } \\
\qquad\left(\mathrm{kJ} / \mathrm{m}^{2}\right)\end{array}$ \\
\hline \multirow{4}{*}{ D-bolt $(20 \mathrm{~mm})$} & 3-2-3 pattern & 225 & 48 \\
\hline & 1.1 bolts $/ \mathrm{m}^{2}$ & & \\
\hline & 4-3-4 pattern & 340 & 73 \\
\hline & 1.6 bolts $/ \mathrm{m}^{2}$ & & \\
\hline \multirow{4}{*}{ D-bolt (22 mm) } & 3-2-3 pattern & 270 & 60 \\
\hline & 1.1 bolts $/ \mathrm{m}^{2}$ & & \\
\hline & 4-3-4 pattern & 405 & 90 \\
\hline & 1.6 bolts $/ \mathrm{m}^{2}$ & & \\
\hline
\end{tabular}


The conceptual load-bearing and energy-absorption capacities presented in Table 5 are considerably high when compared to the conceptual capacities of other ground support systems reported in the collected rockburst case studies from Mines A, B, and C (Figure 9). Although the performance under dynamic-loading conditions of ground support systems comprising D-bolts have not been assessed as part of this study, the conceptual capacities derived from laboratory testing results demonstrate that reinforcement elements required to increase both the load-bearing and energy-absorption capacities of ground support systems are available.

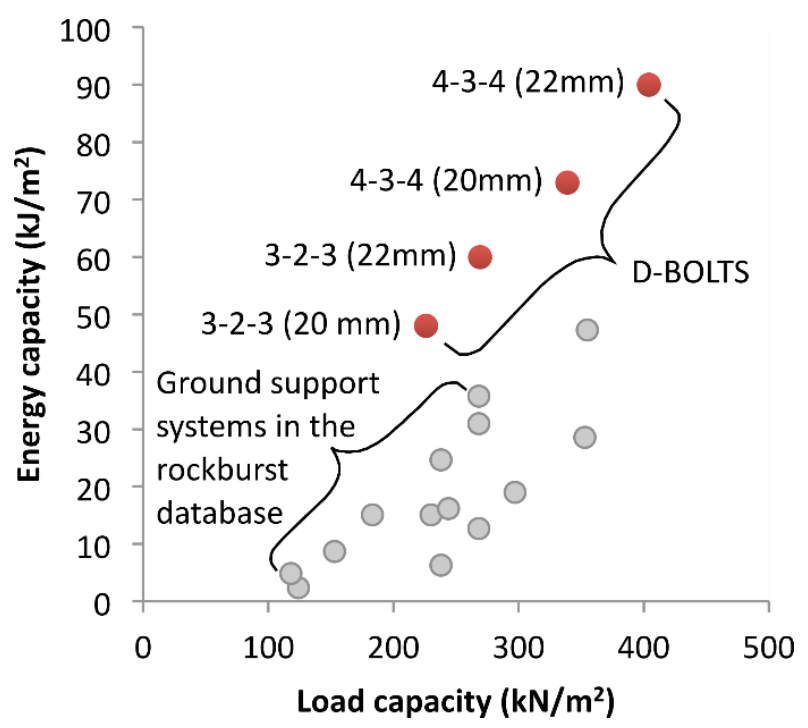

Figure 9 Conceptual load and energy capacities of D-bolt configurations as compared to other reinforcement configurations reported in the rockburst database

Based on the conceptual capacity results (Table 5), the D-bolt, or bolts of similar concept, is an important tool that should be integrated going forward as part of dynamic ground support strategies. It is recognised that maximum performance for a ground support system will only be attained if all elements (bolt, plates, and surface support) are compatible.

\section{Conclusion}

In a deep and high stress mine, the seismic risk can vary in time and space. Hence, it is important to trace the evolution of the seismic risk as mining progresses. This represents a considerable, and continuous challenge for ground control personnel.

A rockburst database that comprised 209 seismic events and the resulting damage to 324 mine openings, that occurred at three mines over 8 to 14 years was constructed, validated, and analysed to provide guidelines for the selection of ground support strategies. Of interest is the ability to integrate new ground support systems in potential scenarios, provided there is adequate technical information being available.

The methodology provided in this work was based on data from three mines in the same mining district. The specific recommendations can potentially be applied to other mines for assessing the location and timing of installation of enhanced ground support, provided site-specific calibration is undertaken to gain confidence in the recommendations.

\section{Acknowledgement}

The authors acknowledge the collaboration of participating mines in developing the rockburst database. 


\section{References}

Durrheim, RJ 2012, 'Functional specifications for in-stope support based on seismic and rockburst observations in South African mines', in Y Potvin (ed.), Proceedings of the Sixth International Seminar on Deep and High Stress Mining, Australian Centre for Geomechanics, Perth, pp. 41-55.

Hedley, DGF 1992, Rockburst Handbook for Ontario Hardrock Mines, No. SP92-1E, CANMET, Ottawa.

Hudyma, MR 2008, Analysis and Interpretation of Clusters of Seismic Events in Mines, Doctoral dissertation, University of Western Australia, Perth.

Kaiser, PK, McCreath, DR \& Tannant, DD 1996, Canadian Rockburst Support Handbook, Canadian Rockburst Research Program 1990-1995, Canadian Mining Industry Research Organization, Sudbury.

Kaiser, PK, Tannant, DD, McCreath, DR \& Jesenak, P 1992, 'Rockburst damage assessment procedure', in PK Kaiser \& DR McCreath (eds), Rock Support in Mining and Underground Construction, Balkema, Rotterdam, pp. 639-647.

Li, CC 2012, 'Performance of D-bolts under static loading', Rock Mechanics and Rock Engineering, vol. 45, pp. $183-192$.

Mikula, P 2012, 'Progress with empirical charting for confident selection of ground support in seismic conditions', in Y Potvin (ed.), Proceedings of the Sixth International Seminar on Deep and High Stress Mining, Australian Centre for Geomechanics, Perth, pp. 71-90.

Milev, AM, Spottiswoode, SM, Noble, BR, Linzer, LM, van Zyl, M, Daehnke, A \& Acheampong, E 2002, The Meaningful Use of Peak Particle Velocities at Excavation Surfaces for the Optimisation of the Rockburst Criteria for Tunnels and Stopes, SIMRAC Final Project Report GAP 709 No. 2002 - 0305, CSIR: Division of Mining and Technology.

Morissette, P, Hadjigeorgiou, J, Punkkinen, AR 2016, 'Characterisation of Burst-Prone Grounds at Vale's Creighton Mine', Mining Technology, viewed 14 November 2016, http://www.tandfonline.com/doi/full/10.1080/14749009.2016.1252093

Morissette, P, Hadjigeorgiou, J, Thibodeau, D 2014a, 'Investigating the dynamic-load demand on support systems using passive monitoring data', International Journal of Rock Mechanics \& Mining Sciences, vol. 67, pp. 115-126.

Morissette, P, Hadjigeorgiou, J, Punkkinen, AR \& Chinnasane, DR 2014b, 'The influence of change in mining and ground support practice on the frequency and severity of rockbursts', in M Hudyma \& Y Potvin (eds), Proceedings of the Seventh International Seminar on Deep and High Stress Mining, Australian Centre for Geomechanics, Perth, pp. 165-177.

Morissette, P, Hadjigeorgiou, J \& Thibodeau, D 2012, 'Validating a support performance database based on passive monitoring data', In Y Potvin (ed.), Proceedings of the Sixth International Seminar on Deep and High Stress Mining, Australian Centre for Geomechanics, Perth, pp. 27-39.

Potvin, Y \& Wesseloo, J 2013, 'Towards an understanding of dynamic demand on ground support', Journal of the Southern African Institute of Mining and Metallurgy, vol. 113, no. 12, pp. 913-922.

Ward, JH 1963, 'Hierarchical grouping to optimize an objective function', Journal of the American Statistical Association, vol. 58, no. 301, pp. 236-244. 
The development of a ground support design strategy for deep mines subjected to dynamic-loading conditions 